\title{
Diversity of reef fish in Halang Melingkau Island, South Kalimantan, Indonesia
}

\author{
FRANS TONY ${ }^{1,2, \vartheta}$, SOEMARNO $^{3}$, DEWA GEDE RAKA WIADNYA ${ }^{4}$, LUCHMAN HAKIM $^{5}$ \\ ${ }^{1}$ Doctoral Program, Department of Agriculture Science, Universitas Brawijaya. J1. Veteran, Malang 65145, East Java, Indonesia. \\ Tel.: +62-341-551665, 565845, Fax.: +62-341-560011, `email: ftony@ulm.ac.id \\ ${ }^{2}$ Department of Marine Science, Faculty of Fisheries and Marine Science, Universitas Lambung Mangkurat. Jl. A. Yani, Banjarbaru 70714, South \\ Kalimantan, Indonesia \\ ${ }^{3}$ Department of Agroecotechnology, Faculty of Agriculture, Universitas Brawijaya. Jl. Veteran, Malang 65145, East Java, Indonesia \\ ${ }^{4}$ Department of Fisheries and Marine Resources Utilization, Faculty of Fisheries and Marine Science, Universitas Brawijaya. Jl. Veteran, Malang 65145, \\ East Java, Indonesia \\ ${ }^{5}$ Department of Biology, Faculty of Mathematics and Natural Sciences, Universitas Brawijaya. Jl. Veteran, Malang 65145, East Java, Indonesia
}

Manuscript received: 4 May 2020. Revision accepted: 25 September 2020.

\begin{abstract}
Tony F, Soemarno, Wiadnya DGR, Hakim L. 2020. Diversity of reef fish in Halang Melingkau Island, South Kalimantan, Indonesia. Biodiversitas 21: 4804-4812. Reef fish is one benchmark to determine a coral reef ecosystem's biodiversity. Reef fish communities are important in coral reef ecosystems because of their trophic relationships with other biotic components. The aim of this study was to determine the biodiversity of reef fish on Halang Melingkau Island, Kotabaru District, South Kalimantan, Indonesia. This research was conducted in March-August 2019. Coral reef fish data were collected using an underwater visual census method. Transects were applied as close as possible to the substrate using a $50 \mathrm{~m}$ roll-up measuring tape. Three transects were applied at each station. A total of 98 reef fish species from 19 families were recorded in this study. The fish community in Halang Melingkau island belongs to the family of Pomacentridae, Labridae, Chaetodontidae, Scaridae, Haemulidae, Lutjanidae, Scolopsidae, Serranidae, Caesionidae, Holocentridae, Siganidae, Pomacanthidae, Apogonidae, Pempheridae, Scorpaenidae, Tetraodontidae, Blenniidae, Platacidae, and Zanclidae. The highest abundance of reef fish was $1.88 \mathrm{ind} / \mathrm{m}^{2}$, and the lowest was $0.14 \mathrm{ind} / \mathrm{m}^{2}$. The dominance index (C) ranged from 0.03 to 0.13 , the homogeneity index ( $\left.\mathrm{E}^{\prime}\right)$ ranged from 0.72 and 0.94 , and the diversity index $\left(\mathrm{H}^{\prime}\right)$ ranged from 2.17 to 3.53 . Water quality data measurements of temperature, brightness, current speed, $\mathrm{pH}$, and DO (Dissolved Oxygen) were within the tolerance limits of water quality standards based on the Minister of Environment Decree No. 51 of 2004, Republic of Indonesia.
\end{abstract}

Keywords: Coral reef fish, Halang Melingkau, Kotabaru, South Kalimantan

\section{INTRODUCTION}

Reef fish is one of the benchmarks for assessing the level of biodiversity of a coral reef ecosystem. The coral reef is a habitat for reef fish with high biodiversity (Allen 2008). Reef fish communities will grow and develop in habitat, with food and shelter (Nikijuluw 2018). Healthy coral reef ecosystems store the biodiversity value of reef fish. Fish comprise one of the biotic components in the coral reef ecosystem and fill very specific micro-habitats of the coral reefs (Messmer et al. 2011; Coker et al. 2013; Komyakova et al. 2018). Several studies have mentioned that sparkling fish communities are important in coral reef ecosystems due to their trophic relationships with other biotic components (Maduppa et al. 2012; Duffy et al. 2016). Live reef fish provide food and other coastal communities (Hoegh-Guldberg 2010; Khasanah et al. 2019).

Damage to coral reefs affects the condition of fish that make the coral reef ecosystem their home (Harvey et al. 2018). Reef fish live and find food in the coral reefs (sedentary), so if coral reefs are damaged, the reef fish will lose their habitat (Cole et al. 2008; Fenner 2012). In 2003, it was estimated that only 7\% of Indonesia's coral reefs were in good condition (Fadli 2009). More than 27\% were in fair condition, and more than $36 \%$ were reported in bad condition. Both natural and anthropogenic factors are involved in the degradation of coral reef ecosystems in Indonesia (Baum et al. 2015). According to Munasik and Siringoringo (2011), the coral community in the South Kalimantan Province of Indonesia was unstable and depressed because it was influenced by land runoff originating from the Barito River.

The distribution, diversity, and growth of coral reefs affect reef fish diversity. Therefore, to maintain reef fish diversity in coral reef ecosystems, environmental factors such as light intensity, exposure level, water temperature, currents, water turbidity, and salinity need to be considered. Suspended solids are a physical-chemical factor that affects coral life. The light factor and the level of exposure are the main drivers affecting the growth of coral reefs. Temperature also has a significant global role (Saptarini et al. 2017).

A previous study on reef fish diversity in Kalimantan, Indonesia, namely in the waters of Maratua Island, East Kalimantan, recorded the number of individuals 690 species of reef fish $/ 250 \mathrm{~m}^{2}$ (Madduppa et al. 2012); in Bontang waters, East Kalimantan recorded 1162 reef fish (Eryati et al. 2015); in Mahakam waters, East Kalimantan, there are 608 marine fish species, which are dominated by 
Arius sp. and Nibea sp. (Suyatna et al. 2017); and in Berau waters, East Kalimantan which recorded 875 species with reef fish diversity index 316 (Nikijuluw 2018). Until now, no one has reported the diversity of reef fish species from the waters of Kotabaru, South Kalimantan, especially in Halang Melingkau Island.

Kotabaru District is one of 11 regencies in South Kalimantan Province, Indonesia. Geographically, Kotabaru is located from $3^{\circ} 10^{\prime}$ to $4^{\circ} 20^{\prime} \mathrm{S}$ and from $115^{\circ} 25^{\prime}$ to $116^{\circ} 20^{\prime}$ E. This area is $9,422.46 \mathrm{~km}^{2}$, comprising $25.21 \%$ of the area of South Kalimantan Province. Kotabaru District consists mainly of one large island and 140 small islands (McElroy 2006). Halang Melingkau Island is one of the islands to be included in a marine nature park based on Kotabaru Regional Regulation No. 11 of 2012 concerning Spatial Planning for Kotabaru District in 2012-2032. This regulation is in accordance with provisions regarding the marine nature park in the South Kalimantan Province Regional Regulation, Republic of Indonesia No. 9 of 2015 concerning the Regional Spatial Planning of South Kalimantan Province in 2015-2035.

The management of coral reef ecosystems in South Kalimantan should be sustainable. Therefore, management and development patterns are needed to preserve, conserve, and study more deeply the condition of reef fish so that species and their numbers can be known in these waters. This knowledge is necessary for proper management and to reduce the negative impact of utilization in the future. This study aimed to determine the reef fish biodiversity on Halang Melingkau Island, Kotabaru District, South Kalimantan Province, Indonesia.

\section{MATERIALS AND METHODS}

\section{Study area}

The subject of this research was coral reef fish found on Halang Melingkau Island, Kotabaru District, South Kalimantan Province, Indonesia. The research site comprised six stations with 18 observation points that were considered representative of the conditions of reef fish in the waters of the island. A brief description of a point of observation can be seen in Figure 1. The coordinates of the observation points are presented in Table 1.

\section{Data collection method}

Coral reef fish data were collected using an underwater visual census (UVC) method (English et al. 1994; Prato et al. 2017). Transects were laid as close as possible to the substrate using a $50 \mathrm{~m}$ roll-up measuring tape. From the selected starting point, each transect was laid parallel to the coastline. Three transects were laid at each station. Observations were made in a $5 \mathrm{~m}$ wide belt transect centered on the transect tape, giving a total observation area of $750 \mathrm{~m}^{2}$ at each station. The substrate composition was recorded using the line intercept transect (LIT) method based on that of English et al. (1997). The advantage of the LIT method is the accuracy of the data. The data obtained are of better quality and greater quantity. The LIT method can also more thoroughly present community structures, such as the percentage of live or dead coral cover, colony size, and species diversity. In addition, the LIT method can provide high-quality data on the structure of the biota community that is symbiotic with coral reefs (Lam et al. 2006).

Observations were made using a $50 \mathrm{~m}$ transect by installing the transect parallel to and following the coastline. The observers waited at the start point for about five minutes after the transect line was laid. This time was used to gain a general picture of the reef fish present at the observation site, while allowing time for the fish to return to normal behavior after the disturbance caused by laying the transect. Fish species seen within a distance of $2.5 \mathrm{~m}$ to the left and right of the transect line were then recorded on a slate. Observations were made using the underwater visual census (UVC) method. Observations of the special characteristics of the fish bodies (mouth shape, body shape, fins, color) were recorded directly by one observer drawing on waterproof paper and documented by other observers using a camera (in the form of photos or videos).

Table 1. Coordinates of the observation points

\begin{tabular}{|c|c|c|c|c|c|}
\hline \multicolumn{2}{|c|}{ Stations } & \multicolumn{2}{|c|}{ Coordinates } & \multirow{2}{*}{$\begin{array}{c}\text { Depth }(\mathbf{m}) \\
1-2\end{array}$} & \multirow{2}{*}{$\begin{array}{c}\text { Way of observation } \\
\text { Snorkeling }\end{array}$} \\
\hline 1 & 1.1 & $116^{\circ} 36^{\prime} 49.567^{\prime \prime} \mathrm{E}$ & $3^{\circ} 39^{\prime} 26.781^{\prime \prime} \mathrm{S}$ & & \\
\hline & 1.2 & $116^{\circ} 36^{\prime} 49.000^{\prime \prime} \mathrm{E}$ & $3^{\circ} 39^{\prime} 27.382^{\prime \prime} \mathrm{S}$ & $1-2$ & Snorkeling \\
\hline & 1.3 & $116^{\circ} 36^{\prime} 48.133^{\prime \prime} \mathrm{E}$ & $3^{\circ} 39^{\prime} 28.065^{\prime \prime} \mathrm{S}$ & $6-8$ & Diving \\
\hline \multirow[t]{3}{*}{2} & 2.1 & $116^{\circ} 36^{\prime} 51.714^{\prime \prime} \mathrm{E}$ & $3^{\circ} 39^{\prime} 16.754^{\prime \prime} \mathrm{S}$ & $1-2$ & Snorkeling \\
\hline & 2.2 & $116^{\circ} 36^{\prime} 50.996^{\prime \prime} \mathrm{E}$ & $3^{\circ} 39^{\prime} 16.418^{\prime \prime} \mathrm{S}$ & $1-3$ & Snorkeling \\
\hline & 2.3 & $116^{\circ} 36^{\prime} 50.118^{\prime \prime} \mathrm{E}$ & $3^{\circ} 39^{\prime} 16.158^{\prime \prime} \mathrm{S}$ & $7-9$ & Diving \\
\hline \multirow[t]{3}{*}{3} & 3.1 & $116^{\circ} 36^{\prime} 59.167^{\prime \prime} \mathrm{E}$ & $3^{\circ} 39^{\prime} 15.242^{\prime \prime} \mathrm{S}$ & $1-2$ & Snorkeling \\
\hline & 3.2 & $116^{\circ} 36^{\prime} 59.628^{\prime \prime} \mathrm{E}$ & $3^{\circ} 39^{\prime} 14.814^{\prime \prime} \mathrm{S}$ & $2-3$ & Snorkeling \\
\hline & 3.3 & $116^{\circ} 37^{\prime} 0.600^{\prime \prime} \mathrm{E}$ & $3^{\circ} 39^{\prime} 14.077^{\prime \prime} \mathrm{S}$ & $7-8$ & Diving \\
\hline \multirow[t]{3}{*}{4} & 4.1 & $116^{\circ} 37^{\prime} 1.533^{\prime \prime} \mathrm{E}$ & $3^{\circ} 39^{\prime} 20.139^{\prime \prime} \mathrm{S}$ & $1-2$ & Snorkeling \\
\hline & 4.2 & $116^{\circ} 37^{\prime} 2.222^{\prime \prime} \mathrm{E}$ & $3^{\circ} 39^{\prime} 20.555^{\prime \prime} \mathrm{S}$ & $1-3$ & Snorkeling \\
\hline & 4.3 & $116^{\circ} 37^{\prime} 3.070^{\prime \prime} \mathrm{E}$ & $3^{\circ} 39^{\prime} 21.888^{\prime \prime} \mathrm{S}$ & $6-7$ & Diving \\
\hline \multirow[t]{3}{*}{5} & 5.1 & $116^{\circ} 36^{\prime} 54.392^{\prime \prime} \mathrm{E}$ & $3^{\circ} 39^{\prime} 29.445^{\prime \prime} \mathrm{S}$ & $1-2$ & Snorkeling \\
\hline & 5.2 & $116^{\circ} 36^{\prime} 54.354^{\prime \prime} \mathrm{E}$ & $3^{\circ} 39^{\prime} 29.981 " \mathrm{~S}$ & $2-3$ & Snorkling \\
\hline & 5.3 & $116^{\circ} 36^{\prime} 54.657^{\prime \prime} \mathrm{E}$ & $3^{\circ} 39^{\prime} 31.608^{\prime \prime} \mathrm{S}$ & $6-8$ & Diving \\
\hline \multirow[t]{2}{*}{6} & 6.1 & $116^{\circ} 37^{\prime} 3.784^{\prime \prime} \mathrm{E}$ & $3^{\circ} 39^{\prime} 22.178^{\prime \prime} \mathrm{S}$ & $10-11$ & Diving \\
\hline & 6.2 & $116^{\circ} 37^{\prime} 0.905^{\prime \prime} \mathrm{E}$ & $3^{\circ} 39^{\prime} 27.436^{\prime \prime} \mathrm{S}$ & $8-10$ & Diving \\
\hline
\end{tabular}




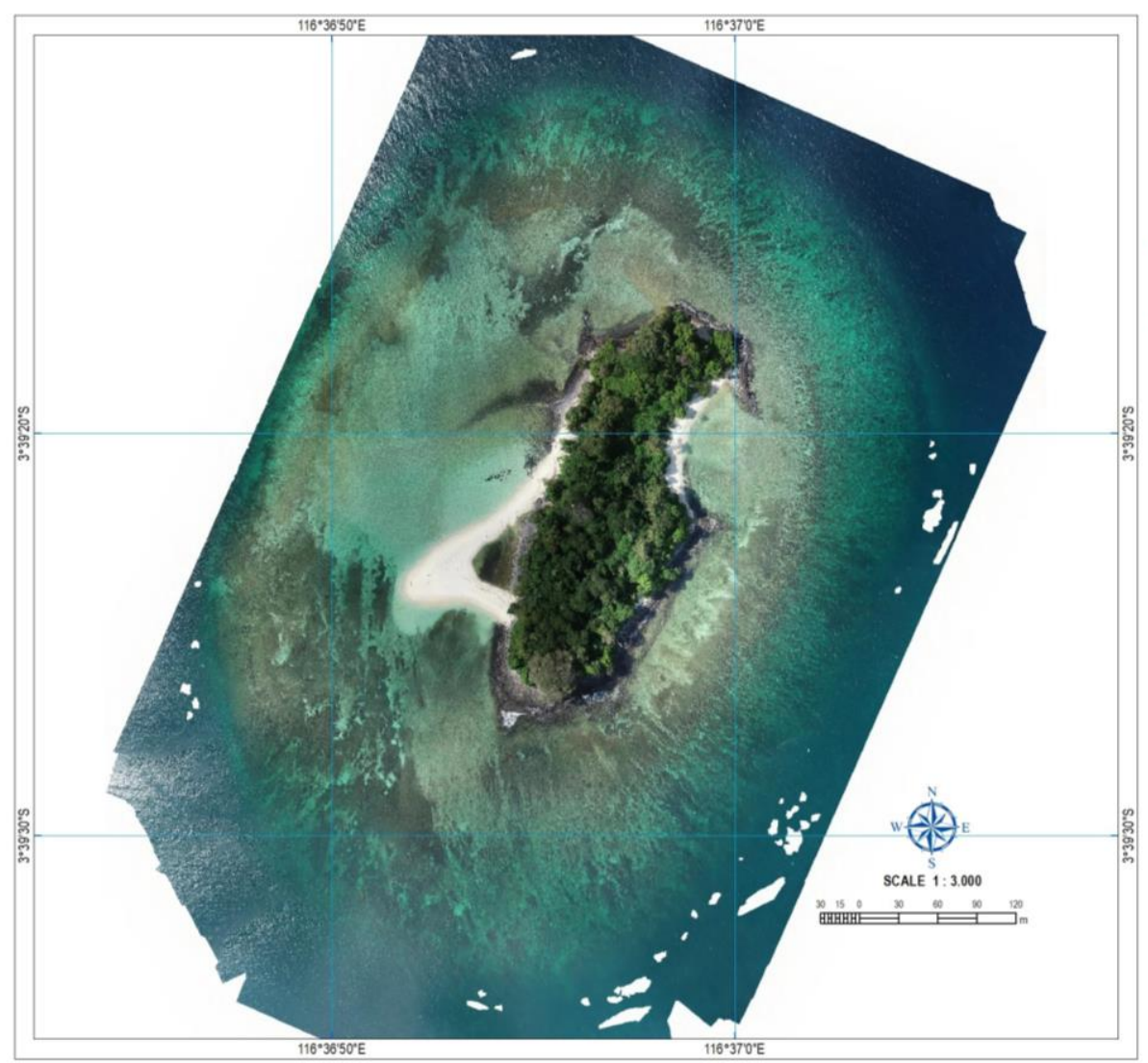

MAPS OF PULAU HALANG MELINGKAU
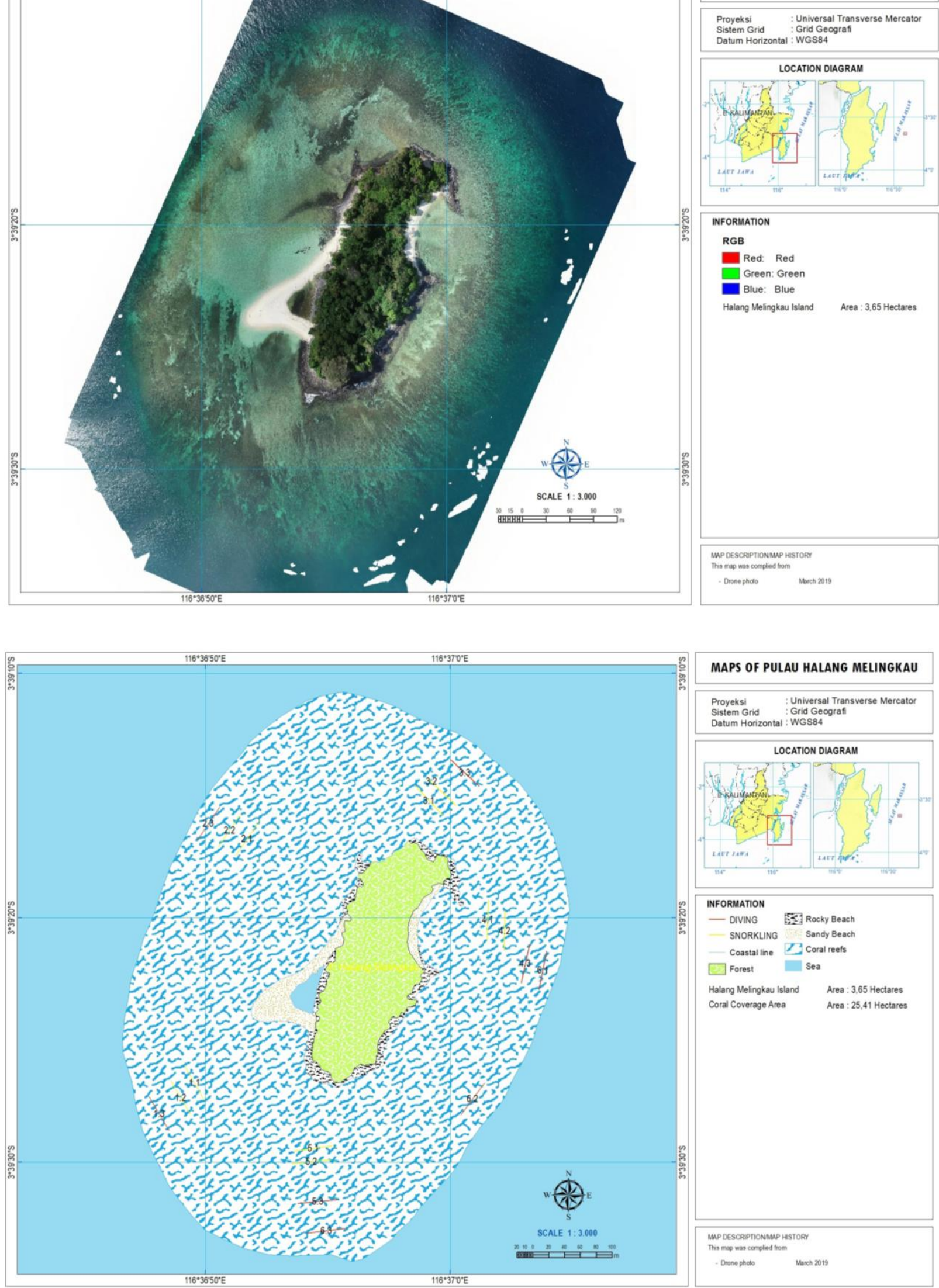

MAPS OF PULAU HALANG MELINGKAU

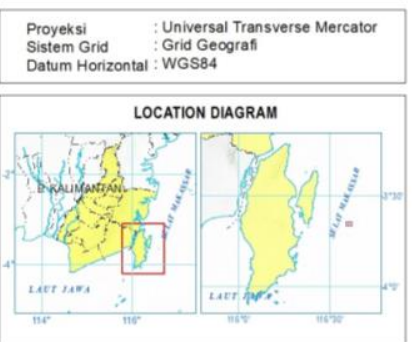

$$
\begin{aligned}
& \text { INFORMATION } \\
& \text { - DIVING } \\
& \text { SNORKLING } \\
& \text { Coastal line } \\
& \text { Cocky Beach } \\
& \text { Coral reets }
\end{aligned}
$$

$\square$ Forest $\quad$ Sea

Halang Melingkau Island Area : 3,65 Hectares

Coral Coverage Area Area : 25,41 Hectares

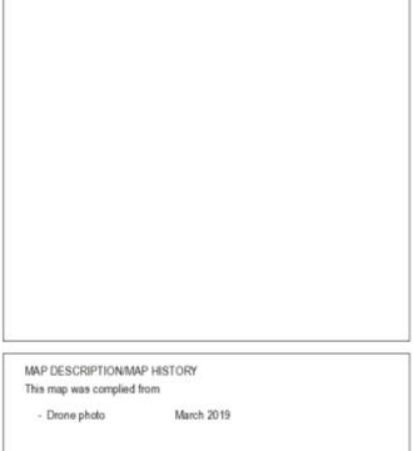

Figure 1. Satellite image of Halang Melingkau Island, Kotabaru District, South Kalimantan Province (A), and map (B) showing the reef fish biodiversity survey stations. 
The transect was also recorded using an underwater camera that had been set to video mode. Fish abundance was calculated using a monitoring distance covering $2.5 \mathrm{~m}$ to the left and right of the transect for fish less than $35 \mathrm{~cm}$ and covering a distance of $5 \mathrm{~m}$ to the left and right for fish measuring $\geq 35 \mathrm{~cm}$ (English et al. 1997). Coral reef fish species that could not be directly identified by the observers were briefly described on the slate and/or photographed. These fish were then identified using the identification key in Kuiter (1992). Fish and coral data were collected sequentially. After the fish data collection was complete, there was a pause for a few minutes followed by the collection of coral data (Levinton 2013). As supporting data, physical and chemical environmental parameters were measured: current speed $(\mathrm{m} / \mathrm{s}$ by a current meter), brightness ( $\mathrm{m}$ by a Sechi disk), temperature $\left({ }^{\circ} \mathrm{C}\right.$ by a thermometer), $\mathrm{pH}$ ( $\mathrm{pH}$ meter), salinity (\%o by a refractometer) and dissolved oxygen $(\mathrm{mg} / \mathrm{L}$ by a $\mathrm{DO}$ meter) at each reef fish observation station.

\section{Data analysis}

The data were tabulated and analyzed in MS Excel 2010. Ecological indices, including abundance, dominance index (C), homogeneity index (E'), and Shannon Wiener diversity index (H') were calculated and analyzed descriptively using figures and tables.

\section{Coral reeffish abundance}

Abundance of coral reef fishes was calculated using the equation below (English et al. 1994):

$$
N=\frac{n \dot{x}}{A}
$$

Where:

$N$ is fish abundancy (ind/m)

$n i$ is individual number No-I; and

$A$ is area width $\left(\mathrm{m}^{2}\right)$

\section{Dominance Index ( $\left.C^{\prime}\right)$}

Dominance index of coral reef fish is calculated using the equation below:

$$
C=\sum_{i=1}^{s} p i^{2}
$$

Where:

$\mathrm{C}$ is dominance index

$\mathrm{Pi}$ is individual number proportion on coral reef fish $\mathrm{s}$ is species number of coral reef fish

The dominance index value ranged from 1 to 0 which meant that if the value approached 1 then there was a tendency for one individual to dominate another. As for the large percentage of live coral cover, dead coral, and other types of lifeform calculated using the formula by English et al. 1997 as follow:

$$
\mathrm{C}=\frac{\alpha}{A} \times 100 \%
$$

Where:

$\mathrm{C}$ is lifeform $i$ coverage percentage

$\alpha$ is lifeform $i$ transect length

$A$ is transect total length

\section{Homogeneity Index $(E)$}

The index of reef fish homogeneity was calculated using the equation below:

$$
\mathbf{E}=\frac{\mathbf{H}^{\prime}}{\mathbf{H m a x}}
$$

Where:

$\mathrm{E}$ is Homogeneity index

Hmax is Species balance in maximum balance $=\ln \mathrm{s}$

Index values ranged from 0-1 with criteria (Brower and Zar 1977):

$\mathrm{E} \leq 0.4$ : homogeneity is low, community is pressured.

$0.4<\mathrm{E} \leq 0.6$ : homogeneity is moderate, community is unstable.

$\mathrm{E}>0.6$ : homogeneity is high, community is stable

Shannon Wiener Diversity Index ( $\left.H^{\prime}\right)$

The Shannon Wiener diversity index was calculated by criteria according to Brower and Zar (1977):

$$
\mathbf{H}^{\prime}=\sum_{\mathbf{i}=1}^{5} \text { piln pi }
$$

Where:

$\mathrm{H}^{\prime}$ is the Shannon Wiener diversity index.

$\mathrm{S}$ is the number of coral reef fish species.

pi is the proportion of the $\mathrm{i}^{\text {th }}$ coral reef fish species.

$\mathrm{H}^{\prime} \leq 2.30 \quad$ : diversity is low, environment pressure is very strong

$2.30<\mathrm{H}^{\prime} \leq 3.30$ : diversity is moderate, environment pressure is moderate

H'> 3.30 : diversity is high, ecosystem in balance

\section{RESULTS AND DISCUSSION}

\section{Coral reef fish abundance}

There are nineteen families of coral reef fishes at the research location during the observation on Halang Melingkau Island (Table 2).

According to Dartnall and Jones (1986), reef fish are classified into three main groups based on management objectives: (i) target fish (also known as economic fish), which are the main target of fishermen's catch as a source of consumption, and economy; (ii) indicator fish, which indicate the coral condition; and (iii) the major fish group with fish between 5 and $25 \mathrm{~cm}$ whose specific role is unknown apart from the food chain cycle. A total of 19 
families of coral reef fish were observed at the research location on Halang Melingkau Island that comprised 18 observation points in six stations with three transects whose lengths were $50 \mathrm{~m}$ each (Table 2). Within the 19 families of fish, 98 reef fish species were observed with a total of 4300 individuals. The family with the greatest abundance and the most species was the Pomacentridae, Labridae, Chaetodontidae, and Scaridae. The Pomacentridae and Labridae families are part of the major fish group that always dominates in the Halang Melingkau island waters. In addition, this Pomacentridae and Labridae families live on coral reefs throughout their life (English et al. 1997).

The Chaetodontidae family is a true coral reef fish. Its distribution is limited to coral reef ecosystems because of its dependence on coral reefs as its food source (Nugraha et al. 2020), although not all Chaetodontidae fish consume coral polyps as to their primary food. The existence and abundance of the Chaetodontidae family in waters can provide an overview of local coral reefs' conditions.

The results of this study indicated that the Pomacentridae family occupied the top rank of 34 species, the most common of which was Pomacentrus auriventris. A total of 196 species of $P$. auriventris were seen at each station. The genus Pomacentrus was also reported at the Royal Thai Naval Base, Sattahip, Chonburi Province, Thailand (Songploy et al. 2017). The Pomacentridae family was widely distributed in the Indo-Pacific region (Satapoomin 2000). The Pomacentridae and Labridae families were also reported to dominate the Redang Islands' marine fish fauna, Malaysia (Du et al. 2019).

Table 2. Abundance of coral fish observed by group and family

\begin{tabular}{lcc}
\hline Family names & $\begin{array}{c}\text { Species } \\
\text { number }\end{array}$ & $\begin{array}{c}\text { Individual } \\
\text { number }\end{array}$ \\
\hline Major group & 34 & 1788 \\
Pomacentridae & 1 & 62 \\
Apogonidae & 1 & 305 \\
Pempheridae & 8 & 137 \\
Scaridae & 1 & 1 \\
Scorpaenidae & 1 & 2 \\
Tetraodontidae & 10 & 356 \\
Labridae & 1 & 100 \\
Blenniidae & 3 & 21 \\
Holocentridae & 1 & 15 \\
Platacidae & 1 & 34 \\
Zanclidae & & \\
Target group & 4 & 671 \\
Caesionidae & 5 & 79 \\
Haemulidae & 5 & 179 \\
Lutjanidae & 4 & 73 \\
Serranidae & 5 & 162 \\
Scolopsidae & 2 & 56 \\
Siganidae & & \\
Indicator group & 9 & 233 \\
Chaetodontidae & 2 & 26 \\
Pomacanthidae & 98 & 4300 \\
Total (all Stations) & & \\
\hline
\end{tabular}

Manthacitra et al. (1991) reported that the species Chaetodon octofasciatus dominated the Chaetodontidae family in the Gulf of Thailand. Lim and Chou (1991) reported similar findings on Ghost Island and Raffles Light, Singapore, and Adrim (2011) found that $C$. octofasciatus was the dominant species on Bawean Island, Indonesia. In this study, $C$. octofasciatus is also the dominant species in the family Chaetodontidae, with 105 individuals and it was present in all stations except Station 3. The highest number species found in this study was Caesio cuning (family Caesionidae) with 493 individuals. The diversity of fish types and numbers of individuals are shown in Table 3.

Based on the abundance data per station, it was known that Station 6 had the greatest abundance of fish $(1.88$ individuals $\left(\mathrm{Ind} / \mathrm{m}^{2}\right)$, while the lowest abundance was found at station $2\left(0.14 \mathrm{Ind} / \mathrm{m}^{2}\right)$ (Table 3 and Figure 2). The abundances at stations 1,3 , and 5 were $1.09 \mathrm{Ind} / \mathrm{m}^{2}, 1.16$ $\mathrm{Ind} / \mathrm{m}^{2}$, and $0.97 \mathrm{Ind} / \mathrm{m}^{2}$, respectively. The abundance of coral reef fishes at each station during observation on Halang Melingkau Island is shown in Figure 2. One of the factors causing the high abundance of coral reef fish at Station 6 is that the condition of coral reef cover at this station is better than those at other stations. This is consistent with the statement of Karnan (2000) that although reef fish are generally territorial in a coral ecosystem, their presence in waters is influenced by habitat and environmental conditions. Suitable ecological conditions will trigger the arrival of reef fish to inhabit a habitat. In contrast, reef fish cannot tolerate environmental changes that will cause migration to a more suitable place.

\section{Dominance Index (C'), Homogeneity Index (E'), and Diversity Index (H)}

The dominance index $(C)$, homogeneity index (E'), and diversity index $\left(\mathrm{H}^{\prime}\right)$ of coral reef fish observed in this study can be seen in Figure 3 and Table 4. Based on these values, no fish predominated in the study area. There were high levels of homogeneity and stable communities at all observation stations, but diversity varied from high to low.

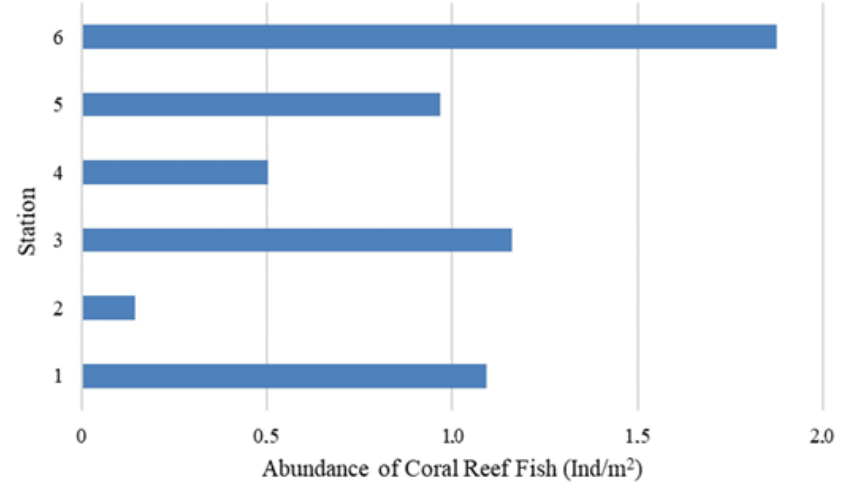

Figure 2. Abundance of coral reef fish at each station $\left(\mathrm{Ind} / \mathrm{m}^{2}\right)$ 
Table 3. Fish diversity and abundance by station.

\begin{tabular}{|c|c|c|c|c|c|c|c|}
\hline \multirow[b]{2}{*}{ Family, species } & \multicolumn{6}{|c|}{ Total } & \multirow{2}{*}{ 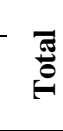 } \\
\hline & $\vec{E}$ & $\tilde{N}$ & $\stackrel{m}{\infty}$ & 志 & $\stackrel{n}{n}$ & 烍 & \\
\hline \multicolumn{8}{|l|}{ Major group } \\
\hline \multicolumn{8}{|l|}{ Pomacentridae } \\
\hline Abudefduf bengalensis & 53 & & 73 & & & & 126 \\
\hline Abudefduf sexfasciatus & 50 & 25 & & 10 & 70 & & 155 \\
\hline Acanthochromis polyacanthus & 34 & & & & & & 34 \\
\hline Amblyglyphidodon aureus & & 12 & & 11 & & 18 & 41 \\
\hline Amblyglyphidodon batunai & & & 4 & & 40 & 4 & 48 \\
\hline Amblyglyphidodon curacao & 14 & & 25 & 24 & 50 & & 113 \\
\hline Amblyglyphidodon leucogaster & 35 & & 22 & & 25 & & 82 \\
\hline Amphiprion ocellaris & 3 & & 2 & 5 & & 7 & 17 \\
\hline Amphiprion clarkii & & & & & & 3 & 3 \\
\hline Amphiprion sebae & & & & & & 5 & 5 \\
\hline Chromis analis & & 6 & 40 & & & 6 & 52 \\
\hline Chromis dimidiata & 14 & & 14 & 20 & 30 & 15 & 93 \\
\hline Chromis flavipectoralis & 26 & & & 12 & & & 38 \\
\hline Chromis & 12 & & 23 & & 50 & & 85 \\
\hline Chromis $x$ & & & & & & 2 & 2 \\
\hline Chrysiptera hemicyanea & & & & & & 32 & 32 \\
\hline Chry & 27 & & & & 11 & 27 & 65 \\
\hline Chry & 17 & & & & & 17 & 34 \\
\hline Dischistodus prosopotaenia & & 11 & & 12 & & & 23 \\
\hline Dischistodus pseudochrysopoecilus & & & & & & 28 & 28 \\
\hline Neopomacentrus cyanomos & & 7 & & 5 & & & 12 \\
\hline Neopomacentrus violascens & & & & & & 9 & 9 \\
\hline Plectroglyphidodon lacrymatus & 11 & & 25 & & & & 36 \\
\hline Pomacentrus alexanderae & & & & & & 30 & 30 \\
\hline Pomacentrus auriventris & 52 & 7 & 60 & 17 & 30 & 30 & 196 \\
\hline Pomacentrus brachialis & & 13 & & 68 & & 13 & 94 \\
\hline Pomacentrus burroughi & 35 & & & & & & 35 \\
\hline Pomacentrus coelestis & 13 & & & 8 & & 8 & 29 \\
\hline Pomacentrus littoralis & & 11 & & 24 & & 26 & 61 \\
\hline Pomacentrus moluccensis & 30 & & & 20 & 30 & & 80 \\
\hline Pomacentrus taeniometopon & & & & 34 & & & 34 \\
\hline Pomacentrus reidi & 34 & & & & & & 34 \\
\hline Premnas biaculeatus & & & & & & 2 & 2 \\
\hline Pristotis obtusirostis & & & & & 60 & & 60 \\
\hline \multicolumn{8}{|l|}{ Apogonidae } \\
\hline Apogon compre & & & 25 & & 12 & 25 & 62 \\
\hline \multicolumn{8}{|l|}{ Pempheridae } \\
\hline Pempheris vanicolensis & 15 & & 23 & 17 & & 250 & 305 \\
\hline \multicolumn{8}{|l|}{ Scaridae } \\
\hline Chlorurus capistratoides & & & & & & 1 & 1 \\
\hline Chlor & 8 & & & & & & 8 \\
\hline Hippo & & & & & & 3 & 3 \\
\hline Scaru & 10 & & 15 & & 11 & & 36 \\
\hline cocaudalis & 15 & & & & & & 15 \\
\hline hobban & 6 & & 18 & & 7 & & 31 \\
\hline Scarus prasiognathos & 7 & & & & & & 7 \\
\hline Scarus quoyi & & & 17 & & 19 & & 36 \\
\hline \multicolumn{8}{|l|}{ Scorpaenidae } \\
\hline Pterois antennata & & & & & & 1 & 1 \\
\hline \multicolumn{8}{|l|}{ Tetraodontidae } \\
\hline Canthigaster papua & & & 2 & & & & 2 \\
\hline \multicolumn{8}{|l|}{ Labridae } \\
\hline Anampses caeruleopunctat & & & & & 8 & & 8 \\
\hline Bodianus bimaculatus & 12 & & 20 & 9 & & & 41 \\
\hline Cheilinus fasciatus & & & & & 10 & & 10 \\
\hline Halichoeres hortulanus & & & & & 20 & 5 & 25 \\
\hline Halichoeres leucoxantus & & & & & & 18 & 18 \\
\hline Halichoeres nortulanus & 17 & & & & & & 17 \\
\hline Halichoeres schwartzii & & & 18 & & & & 18 \\
\hline
\end{tabular}

\begin{tabular}{|c|c|c|c|c|c|c|}
\hline Halichoeres xanti & 20 & & & & & 20 \\
\hline Labroides dimidiatus & 48 & 30 & 12 & 13 & 81 & 184 \\
\hline Thalassoma lunare & & 15 & & & & 15 \\
\hline \multicolumn{7}{|l|}{ Blenniidae } \\
\hline Aspidontus taeniatus & 27 & 28 & & 12 & 33 & 100 \\
\hline \multicolumn{7}{|l|}{ Holocentridae } \\
\hline Myripristis hexagona & & & & & 5 & 5 \\
\hline Sargocentron cornutum & & & & & 8 & 8 \\
\hline Sargocentron rubrum & & & & & 8 & 8 \\
\hline \multicolumn{7}{|l|}{ Platacidae } \\
\hline Platax boersli & & & & 15 & & 15 \\
\hline Zanclidae & & & & & & \\
\hline Zanclus cornutus & & 15 & & 10 & 9 & 34 \\
\hline \multicolumn{7}{|l|}{ arget group } \\
\hline \multicolumn{7}{|l|}{ Caesionidae } \\
\hline Caesio cuning & & 80 & & 15 & 398 & 493 \\
\hline Caesio lunaris & & 20 & & & & 20 \\
\hline Caesio teres & 13 & & & 22 & 23 & 58 \\
\hline Pterocaesio lativittata & & & & & 100 & 100 \\
\hline
\end{tabular}

Haemulidae

Diagramma pictum

Diagramma melanacrum 13

Plectorhinchus

chrysotaenia

Plectropomus flavomaculatus

Plectropomus maculatus 7

Lutjanidae

Lutjanus carponotatus

Lutjanus decussatus

Lutjanus fulviflamma

Lutjanus rufolineatus

Lutjanus vitta

Serranidae

Cephalopholis formosa

Diploprion bifasciatum

Epinephelus merra

Pseudochromis ransonneti 12

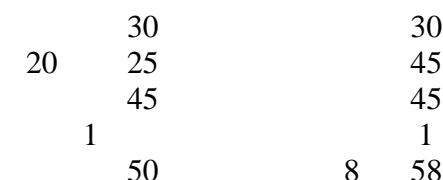

Scolopsidae

Scolopsis bilineata

Scolopsis bilineatus

Scolopsis lineata

Scolopsis temporalis

$5 \quad 5$

13

Scolopsis vosmeri

Siganidae

Siganus guttatus

Siganus vulpinus

Indicator group

Chaetodontidae

Chaetodon lunulatus

Chaetodon modestus

Chaetodon melannotus

Chaetodon octofasciatus

Chaetodon trifascialis

Chaetodon vagabundus

Chelmon rostratus

Coradion chrysozonus

Coradion altivelus

Pomacanthidae

Chaetodontoplus mesoleucus

Pomacentrus annularis

Fish per station

4

15

$8 \quad 22$

31

30

45

1

858

Species per station

Total number of species

$\begin{array}{cccccc} & & & 16 & 16 \\ 15 & 17 & & 15 & & 47 \\ 18 & 35 & & 21 & & 74 \\ & 24 & & & & 24 \\ & & & & 1 & 1 \\ & & & & & \\ & & 3 & & 16 & 19 \\ 12 & & 14 & 11 & & 37\end{array}$

$3 \quad 11$

$\begin{array}{lrr}7 & 7 \\ & 17 \quad 17\end{array}$

$\begin{array}{llllll}25 & 12 & 13 & 18 & 37 & 105\end{array}$

$5 \quad 38$

$10 \quad 10$

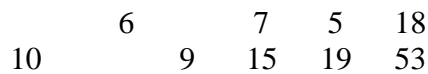

44

22

$\begin{array}{llcrr}14 & 10 & 24 \\ 820105864 & 378 & 725 & 1408 & 4300\end{array}$

$\begin{array}{lllllll}42 & 10 & 34 & 23 & 33 & 52 & 194\end{array}$

98 


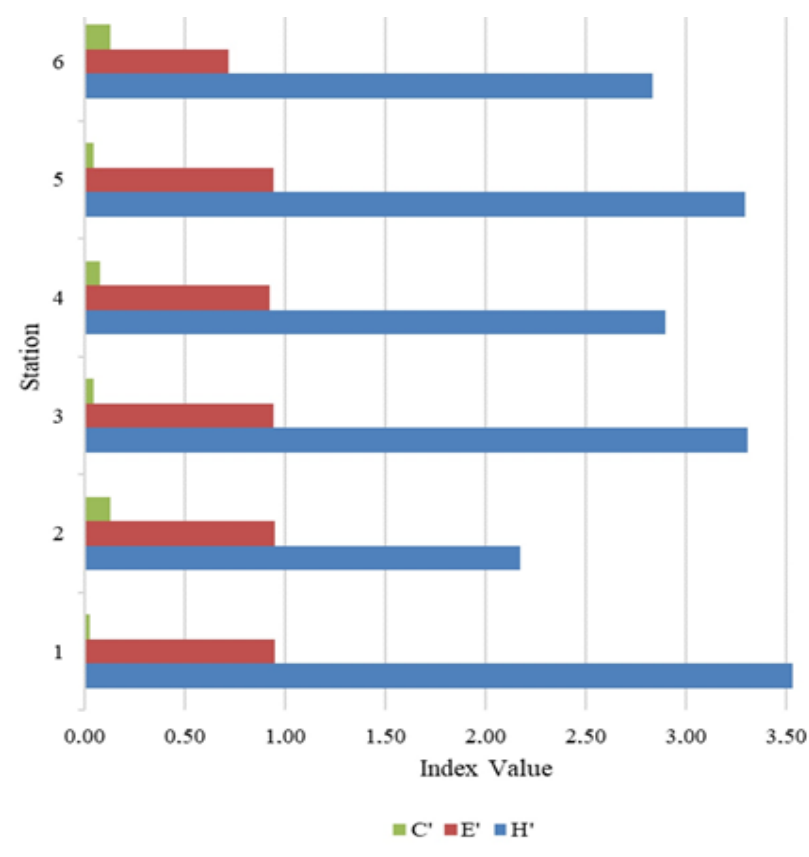

Figure 3. Dominance index value (C), homogeneity index (E'), and diversity index $\left(\mathrm{H}^{\prime}\right)$

\section{Water quality}

The habitat conditions of a coral reef ecosystem will have an influence on the biota that lives in it (Chong-Seng et al. 2012). The waters on Halang Melingkau Island in Kotabaru District, South Kalimantan Province had sandy bottoms and coral reefs that were mostly live corals. The water quality based on data obtained from the side locations at each station during observations on Halang Melingkau Island can be seen in Table 5.

Water temperature is one of the most important factors for the life of organisms in the ocean because the temperature can affect the metabolic activities and proliferation of these organisms (Yao and Somero 2014). The temperature range quality standard for seawater biota according to the Minister of Environment Decree No. 51 of 2004, Republic of Indonesia, is 28 to $30^{\circ} \mathrm{C}$. The water temperatures observed during this study ranged from 29.94 to $30.83^{\circ} \mathrm{C}$, which met the requirements for the survival of coral reef fish or was in the range of the quality standard threshold for seawater biota. According to Al-Malik (2016), the temperature is the environmental factor that has the most significant influence on the growth of marine organisms such as corals. Suharsono (1998) stated that the temperature range that corals can tolerate is $26^{\circ} \mathrm{C}$ to $34^{\circ} \mathrm{C}$. The observed temperature conditions supported coral growth and indicated that the coral reef ecosystems at the observation locations were in good and stable conditions, supporting a high abundance of reef fish in the waters around Halang Melingkau Island.

Brightness is an essential factor for reef fish habitats. It is related to the zooxanthellae's photosynthetic process and the association with corals in terms of providing food. Water absorbs light very strongly. As a result, light entering water can penetrate only to a certain depth before being completely absorbed. Most of the volume of water in the ocean is in a state without light (Osinga et al. 2008). The absorption of light by water varies greatly depending on the wavelength, with certain wavelengths of light penetrating water more deeply than others (Cooper et al. 2009; Hoey et al. 2016). Table 5 shows that the light at all stations could reach the bottom of the water (100\%) except at station 6 , where it reached only a depth of $6.16 \mathrm{~m}$ out of a total depth of $8 \mathrm{~m}(77 \%)$. However, station 6 had the greatest abundance of reef fish compared to other stations. This was presumably because the water quality at station 6 exceeded the specified quality standard, ranging from a depth of $5 \mathrm{~m}$.

Table 4. Values and criteria of dominance index (C), homogeneity index (E') and Shannon Wiener diversity index (H') of reef fish

\begin{tabular}{|c|c|c|c|c|c|c|}
\hline \multirow{2}{*}{ Station } & \multicolumn{2}{|c|}{ Dominance Index } & \multicolumn{2}{|c|}{ Homogeneity Index } & \multicolumn{2}{|c|}{ Shannon Wiener Diversity Index } \\
\hline & $\mathbf{C}^{\prime}$ & Category & $\mathbf{E}^{\prime}$ & Category & $\mathbf{H}^{\prime}$ & Category \\
\hline 1 & 0.03 & None & 0.94 & High, stable & 3.53 & High \\
\hline 2 & 0.13 & None & 0.94 & High, stable & 2.17 & Low \\
\hline 4 & 0.07 & None & 0.92 & High, stable & 2.89 & Moderate \\
\hline 5 & 0.05 & None & 0.94 & High, stable & 3.29 & Moderate \\
\hline 6 & 0.13 & None & 0.72 & High, stable & 2.83 & Moderate \\
\hline
\end{tabular}

Table 5. Seawater quality parameters around Halang Melingkau Island by survey station

\begin{tabular}{|c|c|c|c|c|c|c|c|}
\hline \multirow[b]{2}{*}{ Station } & \multirow[b]{2}{*}{ Coordinate } & \multicolumn{3}{|c|}{ Physical Parameters } & \multicolumn{3}{|c|}{ Chemical Parameters } \\
\hline & & $\begin{array}{c}\text { Temp. } \\
\left({ }^{\circ} \mathrm{C}\right)\end{array}$ & $\begin{array}{l}\text { Brightness } \\
(\mathbf{m})\end{array}$ & $\begin{array}{c}\text { Current } \\
(\mathbf{m} / \mathbf{s})\end{array}$ & $\begin{array}{l}\text { Salinities } \\
(\% \text { ) }\end{array}$ & pH & $\begin{array}{c}\text { DO } \\
(\mathrm{mg} / \mathrm{L})\end{array}$ \\
\hline 1 & $3^{\circ} 39^{\prime} 26.781^{\prime \prime} \mathrm{S} ; 116^{\circ} 36^{\prime} 49.567^{\prime \prime} \mathrm{E}$ & 29.94 & $2.90(100 \%)$ & 0.21 & 31.56 & 7.8 & 9.20 \\
\hline 2 & $3^{\circ} 39^{\prime} 16.754 " \mathrm{~S} ; 116^{\circ} 36^{\prime} 51.714^{\prime \prime} \mathrm{E}$ & 30.30 & $5.50(100 \%)$ & 0.18 & 31.84 & 8.0 & 9.04 \\
\hline 3 & $3^{\circ} 39^{\prime} 15.242 " \mathrm{~S} ; 116^{\circ} 36^{\prime} 59.167^{\prime \prime} \mathrm{E}$ & 30.52 & $3.00(100 \%)$ & 0.14 & 32.04 & 7.9 & 9.22 \\
\hline 4 & $3^{\circ} 39^{\prime} 20.139^{\prime \prime} \mathrm{S} ; 116^{\circ} 37^{\prime} 1.533^{\prime \prime} \mathrm{E}$ & 30.54 & $1.50(100 \%)$ & 0.04 & 31.48 & 7.4 & 9.88 \\
\hline 5 & $3^{\circ} 39^{\prime} 29.445^{\prime \prime} \mathrm{S} ; 116^{\circ} 36^{\prime} 54.392^{\prime \prime} \mathrm{E}$ & 30.46 & $5.00(100 \%)$ & 0.19 & 31.78 & 7.4 & 9.00 \\
\hline 6 & $3^{\circ} 39^{\prime} 22.178^{\prime \prime} \mathrm{S}: 116^{\circ} 37^{\prime} 3.784^{\prime \prime} \mathrm{E}$ & 30.83 & $6.16(77 \%)$ & 0.08 & 32.03 & 7.5 & 9.45 \\
\hline No. 5 & $\begin{array}{l}\text { Minister of Environment Decree } \\
1 \text { of } 2004 \text {, the Republic of Indonesia }\end{array}$ & $28-30{ }^{\circ} \mathrm{C}$ & $>5$ & & $33-34$ & $7-8.5$ & $>5$ \\
\hline
\end{tabular}


Water currents play a role in the process of growing a food supply in the form of plankton and oxygen (Sekerci and Petrovskii 2015; Basu and Mackey 2018). The currents carry oxygen, zooplankton, and nutrients needed for coral growth as the primary habitat for reef fish (Hamner et al. 2007). The water current velocities at the study site ranged from 0.04 to $0.21 \mathrm{~m} / \mathrm{s}$ (Table 3 ). These current velocities were greater than those in the coastal waters of Angsana Subdistrict, Tanah Bumbu, South Kalimantan Province $(0.01-0.05 \mathrm{~m} / \mathrm{s}$ with an average of $0.03 \mathrm{~m} / \mathrm{s}$ ) (Iskandar and Tony 2013). The highest measured current velocity was at station 1 and the lowest was at station 6 , but station 6 had the greatest abundance of fish. These results indicated that water current was not the main factor affecting the abundance of reef fish in these waters.

According to Kültz (2015) and Lehtonen et al. (2016), salinity has an important role a close bond with the life of aquatic organisms including fish. Corals and their associated biota, including reef fish, have a limited ability to tolerate changes in salinity within the range of 25 to $40 \%$ (Smyth and Elliott 2016). Physiologically, salinity is closely related to the adjustment of pressure for the survival of reef fish and is optimal in the range of 30 to $36 \%$. The water salinity in this study ranged from 31.48 to $32.04 \%$, which was below the optimum standard (33 to $34 \%$ ) stipulated in the Minister of Environment Decree No. 51 of 2004, Republic of Indonesia. According to Nugraha et al. (2020), the water condition will influence the abundance of reef fish in the waters.

According to the Minister of Environment Decree No. 51 of 2004, Republic of Indonesia, the best acidity $(\mathrm{pH})$ of seawater for marine biota, including reef fish, is between 7.0 and 8.5. Generally, the $\mathrm{pH}$ of seawater does not vary much because the carbon dioxide system in the water has a strong buffering capacity (Feely et al. 2009; Putri et al. 2015). In this study, the $\mathrm{pH}$ of the water was in the range of 7.4 to 8.0 .

The high value of dissolved oxygen in each ecosystem could be caused by the diffusion of oxygen from free air. Based on the Minister of Environment Decree No. 51 of 2004, the Republic of Indonesia concerning quality standards for marine biota, dissolved oxygen (DO) levels of greater than $5 \mathrm{mg} / \mathrm{L}$ are optimal for aquatic biota growth. Waters with low DO levels would inhibit growth and could cause the death of the biota. According to Faturohman et al. (2016), water with a DO value of less than $3 \mathrm{mg} / \mathrm{L}$ will cause the death of aquatic organisms. The DO in the water in this study was $9.00-9.88 \mathrm{mg} / \mathrm{L}$, which was quite sufficient. This result was in line with the observation of DO in the waters of the southern part of Pulau Laut Village of Tamiang Bay, Pulau Laut Tanjung Selayar Subdistrict, Kotabaru District, South Kalimantan Province, which ranged from 5.8 to $10.8 \mathrm{mg} / \mathrm{L}$ (Sahril 2017).

Based on the study results, it can be concluded that the coral fish community in the waters of Halang Melingkau Island was dominated by major fish family groups, namely Pomacentridae and Labridae. The small number of indicator fish may indicate that the reef fish habitat has been degraded. Therefore, the results of this study are expected to be one of the considerations in management and coastal decision-making on Halang Melingkau Island.

\section{ACKNOWLEDGEMENTS}

The authors deliver the gratitude to the Indonesia Endowment Fund for Education (LPDP), Ministry of Finance, the Republic of Indonesia which supported the fund of this research. The authors are also grateful to the local government of Kotabaru District, Indonesia, and all friends who were supportive so that this research could be completed.

\section{REFERENCES}

Adrim M. 2011. The structure of reef fish communities on Bawean Island. In: Ruyitno MM, Pramuji, Sulistijo, Susana T, Fahmi (eds) Biodiversity in the Bawean Island Water Region. Research center for Oceanography-Indonesian Institute of Sciences, Jakarta. [Indonesian]

Allen GR. 2008. Conservation hotspots of biodiversity and endemism for Indo-Pacific coral reef fishes. Aquatic Conserv: Mar Freshw Ecosyst 18: 541-556.

Al-Malik MD. 2016. Coral reef cover and abundance of reef fish at Pulau Nyamuk, Karimunjawa. Proceedings of Annual Seminar on Fisheries and Marine Science V. Diponegoro University, Semarang, 7 November 2015. [Indonesian]

Basu S, Mackey KRM. 2018. Phytoplankton as key mediators of the biological carbon pump: Their responses to a changing climate. Sustainability 10: 1-18.

Baum G, Januar HI, Ferse SCA, Kunzmann A. 2015. Local and regional impacts of pollution on coral reefs along the Seribu Islands, North of the megacity Jakarta, Indonesia. PLoS One 10: e0138271. DOI: 10.1371/journal.pone.0138271.

Brower JE, and Zar JH. 1977. Field and Laboratory Method for General Ecology. Wm. C Brown Publishing Dubuque, Iowa.

Chong-Seng KM, Mannering TD, Pratchett MS, Bellwood DR, Graham NAJ. 2012. The influence of coral reef benthic condition on associated fish assemblages. PLoS One 7: e42167. DOI: 10.1371/journal.pone.0042167

Coker DJ, Wilson SK, Pratchett MS. 2013. Importance of live coral habitat for reef fishes. Rev Fish Biol Fisher 24: 89-126.

Cole AJ, Pratchett MS, Jones GP. 2008. Diversity and functional importance of coral-feeding fishes on tropical coral reefs. Fish and Fish 9: 286-307.

Cooper TF, Gilmour JP, Fabricius KE. 2009. Bioindicators of changes in water quality on coral reefs: review and recommendations for monitoring programmes. Coral Reefs 28: 589-606.

Dartnall AJ, Jones M. 1986. A Manual of Survey Methods: Living Resources in Coastal Areas. ASEAN-Australia Cooperative Program on Marine Science Handbook. The Australian Institute of Marine Science, Townsville.

Du J, Loh K, Hu w, Zheng X, Affendi YA, Ooi JLS, Ma Z, Rizman-Idid M, Chan AA. 2019. An updated checklist of the marine fish fauna of Redang Islands, Malaysia. Biodivers Data J 7: e47537. DOI: 10.3897/BDJ.7.e47537

Duffy JE, Lefcheck JS, Stuart-Smith RD, Navarrete SA, Edgar GJ. 2016. Biodiversity enhances reef fish biomass and resistance to climate change. Proc Nat Acad Sci 113: 6230-6235.

English S, Wilkinson C, Baker V. 1994. Survey Manual for Tropical Marine Resources. ASEAN-Australia Marine Science Project Living Coastal Resources, Townsville.

English S, Wilkinson C, Baker V. 1997. Survey Manual for Tropical Marine Resources, 2nd Edition. ASEAN-Australia Marine Science Project Living Coastal Resources, Townsville. 
Eryati R, Efendi M, Ritonga IR. 2015. Biodiversity of coral fish in Bontang Waters, East Kalimantan, Indonesia. In: Proceedings of the International Seminar Fisheries and Marine Science in Accordance with Sail Tomini and Festival of Boalemo. Gorontalo State University, Gorontalo, 8-10 September 2015.

Fadli, N. 2009. Growth rate of Acropora formosa fragments that transplanted on artificial substrate made from coral rubble. Biodiversitas 10: 181-186.

Faturohman I, Sunarto, Nurruhwati I. 2016. The correlation of plankton abundance with seawater temperature at Cirebon steam electricity power station. Jurnal Perikanan Kelautan VII: 115-122. [Indonesian]

Feely RA, Orr J, Fabry VJ, Kleypas JA, Sabine CL, Langdon C. 2009. Present and future changes in seawater chemistry due to ocean acidification. Geophys Monogr Ser 183: 175-188.

Fenner D. 2012. Challenges for managing fisheries on diverse coral reefs. Diversity 4: 105-160.

Hamner WM, Colin PL, Hamner PP. 2007. Export-import dynamics of zooplankton on a coral reef in Palau. Mar Ecol Prog Ser 334: 83-92.

Harvey BJ, Nash KL, Blanchard JL, Edwards DP. 2018. Ecosystem-based management of coral reefs under climate change. Ecol Evol 8: 63546368.

Hoegh-Guldberg O. 2010. Coral reef ecosystems and anthropogenic climate change. Reg Environ Change 11: 215-227.

Hoey AS, Howells E, Johansen JL, Hobbs JA. 2016. Recent advances in understanding the effects of climate change on coral reefs. Diversity 8. DOI: $10.3390 / \mathrm{d} 8020012$

Iskandar R, Tony F. 2013. Sedimentation study at Angsana River in Angsana Subdistrict, Tanah Bumbu District, South Kalimantan. Enviro Scienteae 9: 106-111. [Indonesian]

Karnan. 2000. The Spatial-Temporal Association of Coral Communities with Coral Growth Forms in the Waters Southwest of the Island of Sumbawa, East Nusa Tenggara. [Thesis]. IPB University, Bogor. [Indonesian]

Kuiter RH. 1992. Tropical Reef Fish of Western Pacific. Indonesia and Adjacent Waters. PT. Gramedia Pustaka Utama, Jakarta.

Khasanah, RI, Herawati EY, Hariati AM, Mahmudi M, Sartimbul A, Wiadnya DGR, Asrial E, Yudatomo, Nabil E. 2019. Growth rate of Acropora formosa coral fragments transplanted on differen compositions of faba kerbstone artificial reef. Biodiversitas 20: 3593 3598 .

Komyakova V, Jones GP, Munday PL. 2018. Strong effects of coral species on the diversity and structure of reef fish communities: A multi-scale analysis. PLoS One 13: e0202206. DOI 10.1371/journal.pone.0202206

Kültz D. 2015. Physiological mechanisms used by fish to cope with salinity stress. J Exp Biol 218: 1907-1914.

Lam K, Shin PKS, Bradbeer R, Randall D, Ku KKK, Hodgson P, Cheung SG. 2006. A comparison of video and point intercept transect methods for monitoring subtropical coral communities. J Exp Mar Biol Ecol 333: 115-128.

Lehtonen TK, Wong BBM, Kvarnemo C. 2016. Effects of salinity on nest-building behaviour in a marine fish. BMC Ecol 16. DOI: 10.1186/s12898-016-0067-y

Lim GSY, Chou LM. 1991. Studies of reef fish communities in Singapore. In: Alcala AC (eds.). Proceedings of The Regional Symposium on Living Resources in Coastal Areas. University of the Philippines, Manila, 31 January-1 February 1989.

Madduppa HH, Agus SB, Farhan AR, Suhendra D, Subhan B. 2012. Fish biodiversity in coral reefs and lagoon at the Maratua Island, East Kalimantan. Biodiversitas 13: 145-150
Manthacitra V, Sudara S, Satumanapatpan S. 1991. Chaetodon octofasciatus as indicator species for reef condition. In: Alcala AC (eds). Proceedings of The Regional Symposium on Living Resources in Coastal Areas. University of the Philippines, Manila, 31 January-1 February 1989.

Levinton JS. 2013. Marine Biology: Function, Biodiversity, Ecology, 4th Edition. Oxford University Press, Oxford.

McElroy JL. 2006. Small island tourist economies across the life cycle. Asia Pac Viewp 47: 61-77.

Messmer V, Jones GP, Munday PL, Holbrook SJ, Schmitt RJ, Brooks AJ. 2011. Habitat biodiversity as a determinant of fish community structure on coral reefs. Ecology 92: 2285-2298.

Munasik, Siringoringo RM. 2011. Hard coral community structure (Scleractinia) in Marabatuan and Matasirih Islands, South Kalimantan. Indon J Mar Sci 16: 14-21. [Indonesian]

Nikijuluw VPH. 2018. Biodiversity conservation of coastal fish of Indonesia. Indon J Ichthyol 18: 285-296.

Nugraha WA, Mubarak F, Husaini E, Evendi H. 2020. The correlation of coral reef cover and rugosity with coral reef fish density in East Java Waters. Jurnal Ilmiah Perikanan dan Kelautan 12: 131-139. [Indonesian]

Osinga R, Janssen M, Janse M. 2008. The role of light in coral physiology and its implications for coral husbandry. In: Leewis RJ, Janse M (eds). Advances in Coral Husbandry in Public Aquariums. Public Aquarium Husbandry Series, Vol. 2. Burgers' Zoo, Arnhem.

Prato G, Thiriet P, Di Franco A, Francour P. 2017. Enhancing fish underwater visual census to move forward assessment of fish assemblages: An application in three Mediterranean marine protected areas. PLoS One 12: e0178511. DOI: 10.1371/journal.pone.0178511

Putri MR, Setiawan A, Safitri M. 2015. Variation of ocean $\mathrm{pH}$ in the Indonesia waters. AIP Conf Proc 1677: 060021. DOI: $10.1063 / 1.4930701$

Sahril A, 2017. Analysis of Dissolved Oxygen Parameters in Southern Ocean Island Waters as an Indicator of Pollution in Kotabaru District. [Research Report] Lambung Mangkurat University, Banjarbaru. [Indonesian].

Saptarini D, Mukhtasor, Rumengan IFM. 2017. Coral reef lifeform variation around power plant activity: case study on coastal area of Paiton Power Plant, East Java, Indonesia. Biodiversitas 18: 116-120.

Satapoomin U. 2000. A preliminary checklist of coral reef fishes of the Gulf of Thailand, South China Sea. Raffles B Zool 48: 31-53.

Sekerci Y, Petrovskii S. 2015. Mathematical modelling of planktonoxygen dynamics under climate change. Bull Math Biol 77: 23252353.

Smyth K, Elliott M. 2016. Effects of changing salinity on the ecology of the marine environment. In: Solan M, Whiteley NM (eds). Stressors in The Marine Environment-Chapter 9. Oxford University Press, Oxford.

Songploy S, Chavanich S, Kuanui P, Viyakarn V. 2017. Diversity of reef fish at Royal Thai Naval Base, Sattahip, Chonburi Province, Thailand. Indian Geo Mar Sci 46:1220-1225.

Suharsono. 1998. Condition of coral reef resources in Indonesia. Jurnal Pesisir dan Lautan 1 (2): 44-52. [Indonesian]

Suyatna I, Syahrir M, Mislan, Wijaya YI, Abdunnur A. 2017. A survey on Marine Fish Species In River of Mahakam East Kalimantan, Indonesia. Omni-Akuatika 13: 89-98.

Yao CL, Somero GN. 2014. The impact of ocean warming on marine organisms. Chinese Sci Bull 59: 468-479. 